Kendra Camilla Besariani ${ }^{1}$, Moses Glorino Rumambo Pandin ${ }^{2}$

English Language and Literature Study Program, Faculty of Humanities ${ }^{1,2}$

Universitas Airlangga

Jl. Airlangga No.4 - 6, Airlangga, Kec. Gubeng, City of SBY, East Java 60115

ken.camilla.besariani-2020@fib.unair.ac.id and moses.glorino@fib.unair.ac.id

\title{
BOOK REVIEW: \\ MILLENNIAL NATIONALISM: IS IT A DISRUPTION? (NASIONALISME ALA MILENIAL: SEBUAH DISRUPSI?)
}

Aulia Hadi, Anggy Denok Sukmawati, Annisa Meutia Ratri, Dicky Rachmawan, Fachri Aidulsyah, Fanny Henry Tondo, Hidayatullah Rabbani, Jalu Lintang Yogiswara Anuraga, Muhammad Nur Prabowo Setyabudi, Puji Hastuti, Rusydan Fathy, Sentiela Ocktaviana, Thung Ju Lan; South Jakarta; 2021; 978-602496-176-3; 420 pages

A book entitled Nasionalisme ala Milenial: Sebuah Disrupsi? This was written as an attempt to answer a question of one of the authors. According to her, Indonesia is currently in a transition period that can be described in three ways: politics to become more free and open, the population of the younger generation has reached its peak, and the existence of digital technology, which is developing so rapidly. The authors' purpose by writing this is to assist readers, especially the younger generation, in placing themselves in a space for a free, open, and creative future for Indonesia. That way, the millennial generation can embark on a journey to find Indonesia in the future according to their needs and perspectives as a new generation of Indonesian leaders. This book was written for various circles of society, but it is more aimed at the millennial generation. In Revolution 4.0 and Society 5.0, the millennial generation will face challenges that are not easy because the rapid development of information technology forces them to be adaptable, critical, observative, flexible, and visionary to survive in global nial competition. Therefore, it is recommended for millennials to read Nasionalisme Ala Milenial: Sebuah Disrupsi book because the chapters contained in it can inspire millennials to contribute to the country's welfare. This book includes 12 articles that can be grouped into five topics, namely defining millennial youth; establishment of millennial identity; expressions of millennial nationalism; education, youth, and the language of the millennial generation, and millennial citizenship. While reading this, we will understand the descriptions of the writers' intelligence, hopes, and anxieties about the future of Indonesia. The writings in this book contain various thoughts from millennial generation writers. The various ideas about nationalism and millennials in it are also packaged creatively and in detail according to their respective understandings. In addition, the ideas contained in it can be an impetus for millennial readers to maintain better and maintain their nationalism.

\section{REVIEW}

This book itself is intended for all circles of society, especially millennials. The contents explain to the reader that if not all millennials have a waning sense of nationalism, this generation is participating in fighting for the welfare of their country. From this statement, the readers will understand that the writers breaks the stereotypes of the majority of Indonesians that are not true of millennials. The ideas written in it also invite the nation's future youths to continue to uphold a sense of nationalism in themselves so that this book meets the needs of its intended readers.

The book contains interesting new information to present, namely the topic in chapter VII. The chapter discusses fashion trends in millennials that still have nationalistic values. Fashion is an important element of the millennial generation's identity. For this generation, the function of clothing is no longer only for primary needs, namely covering the limbs, but also as an articulation of various forms of expression. It can be interpreted that with someone wearing archipelago-style clothes, he tries to carry out a dressed expression that articulates the values of nationalism. Dressing in traditional clothes continues to be encouraged by many parties, both by the government, society, and designers.

Nasionalisme Ala Milenial: Sebuah Dirsrupsi book is influential for readers to provide a perspective on the millennial generation in responding to Indonesian nationalism. As a new generation dubbed the millennial generation, many people consider the millennial generation to be degraded by many influences so that the value of nationalism fades. The writings are divided into five groups (defining millennial youth; forming millennial identity; expressions of millennial nationalism; education, youth, and the language of the millennial generation; and millennial 
citizenship), may not be able to answer one of the author's question fully, but the writers try to show their love for Indonesia according to their way and understanding. Their educational background and social life directly or indirectly influence them in choosing and writing their discussion topics. The writers' explanations have succeeded in providing an overview of their intelligence, hopes, and worries about the future of Indonesia. It impacts the readers that even though we are the millennial generation, we do not carelessly fight for independence and enliven a sense of nationalism in us. The reason is, the millennial generation will later become future leaders. Do not carelessly fight for independence and enliven a sense of nationalism in us. The reason is, the millennial generation will later become future leaders. Do not carelessly fight for independence and enliven a sense of nationalism in us. The reason is, the millennial generation will later become future leaders.

By giving good influence, this book can help readers, especially young readers, to place themselves in a space for a free, open, and creative future for Indonesia to embark on a journey to discover Indonesia in the future according to their needs and perspectives. The scope of this anthology includes 12 articles which can be grouped into five topics, namely defining millennial youth; millennial identity formation; expressions of millennial nationalism; education, youth, and the language of the millennial generation; and millennial citizenship. For that, readers can have a picture of nationalism from the perspective of the millennial generation.

It is evidence-based on quotes in the paraphrased or quoted book. In addition, other evidence is a picture that explains something accompanied by clarity of the source from which the image was taken. Some pictures are processed from the author himself based on the book's reading the author wants to quote. In addition, there are sections in the book that quote the contents of the newspaper. Some of the sources of writing taken in books come from books, journals, novels, newspapers, articles, and laws.

The evidence contained in it is about $90 \%$ convincing because if a quote is either paraphrased or not, it always includes the identity. Such as, Youth Pledge is the source of the great concept of national unity known as Bhinneka Tunggal Ika (Widodo, 2012). In that sentence, quoting Widodo's book, the author provides a note at the end of the sentence followed by the year the book's publisher was quoted. In addition, the author provides clarity on the identity of the book in the bibliography because it has quoted the contents of the book by Widodo.

On page 110, it is explained that Jackson and Hogg (2010) interpreted that the development of technology, both transportation technology, and information technology, includes the Internet in it, making humans have physical mobility and perceptions that move very quickly. Technology has influenced people's thoughts and actions. Technoscapes and mediascapes can be said to control what humans ultimately do. Perception is determined by the mindset related to one's knowledge (stock of knowledge). This knowledge is often constructed through what humans hear and see in their daily lives. Humans are exposed to ideology, material culture, and global lifestyles with high intensity. Then on pages 129-131, it is explained, Cultural development in Indonesia cannot be separated from the various interactions between ethnic groups from the past to the present. If globalization is defined as connecting people in the world, the interactions that occur between ethnic groups in Indonesia are a form of globalization. For centuries, the cultural history of the archipelago is the result of a meeting of various cultures because Indonesia is a melting pot. This condition makes the Indonesian people familiar with the inclusion of various other cultural values. Management in accepting and filtering other cultures that enter society so far is a value that needs to be maintained. In the current era, when the flow of information is unstoppable, our nation seems shocked by the various values and information that comes in. Our nation's stuttering reaction over this phenomenon is to dichotomy native culture and foreign culture. As a result of this dichotomy, excessive conservatism has emerged, which creates cultural conflicts and assumptions of "antiquity" against existing cultures. Another form that emerges, in this case, can also be a nationalist and non-nationalist dichotomy just because it uses and does not use Indonesian material culture in everyday life. The conservatism that occurs shows a tendency to see local cultures as static, fixed, or fixed. The local culture perceived as static tends to be non-adaptive because the preservation of traditionalism barriers obstructs it.

Furthermore, the foreign culture that enters the country tends to be seen as a threat to local culture. This assumption, in the end, makes people stutter in responding to the demands of changing times. Although this assumption is not wrong, this perception is also not entirely correct. Citizens 
should have the awareness to sort out what should be accommodated and what should be rejected. Fatal conservatism will only be the death knell for local culture. Adapting to foreign cultures is not a foreign thing in Indonesia. Cultural products, such as puppets, Tanjore art, traditional building architecture, batik, and others, show that our culture has had a good strategy in adapting to foreign cultures. These cultures are managed in such a way as to make them very typical of the archipelago or as if they belong to certain regions. Thus, the existing local culture can still exist and transform properly according to the era. The strategy for dealing with foreign cultural currents of globalization is what we are now forgetting. Our forgetfulness of these basic values will weaken the national identity.

The style, organization, and size of this book serve their purpose. This book asks "Is millennial-style nationalism a disruption?" amid the rapid advancement of digital technology and the peak of the millennial generation population. According to the author, this question is quite difficult to find in this book, because the changes caused by advances in information and communication technology have not drastically changed the social order. It means that there has been disruption. Through this book, the author proves that the millennial generation has not been seen to change the values held by society. The reality proves that this generation is interested in discussing their nationalism in the present and the future.

The author has ignored none of the studies, facts, and ideas contained in this book. The writers' thoughts are packaged neatly and clearly. Everything in this book explains the behavior of nationalism in the style of the millennial generation in this all-digital era. There is also a topic in one of the chapters that discusses youth's role in the Youth Pledge era and millennial responses to these historical events. In addition, most of the writers in this book are also from the millennial generation to reflect on themselves. Therefore, the book entitled Nasionalisme ala Millennial: Sebuah Disrupsi? is very much related to millennials.

This book is important to read because it describes the various expressions of the millennial generation in showing the spirit of nationalism to the country in detail but not boring. The language used is also easy to understand. Therefore it makes the reader comfortable. Each chapter inside it covers a different topic and makes readers want to continue reading. In addition, the contents of it will be able to make people aware that the millennial generation is not only a destroyer of the nation, but they make a meaningful contribution to the Indonesian state.

A book entitled Nasionalisme ala Milenial: Sebuah Disrupsi? This raises an interesting topic and is very important for readers, especially millennial youth. However, the writer should pay more attention to the sentence writing, punctuation, and vocabulary errors because some confusing sentences are found. Therefore the readers must read over and over again to understand the meaning. Besides that, some difficult terms are less familiar. The author can improve by giving the meaning of these terms at the bottom of the book. Readers are expected to uphold and still preserve the values of nationalism discussed in this book. In addition, readers can implement the positive things described. Therefore, the millennial generation will build Indonesia's future aspirations amid a global vortex.

\section{REFERENCE}

Hadi, A. et al. (2021). Nasionalisme Ala Milenial: Sebuah Disrupsi?. South Jakarta: LIPI Press 


\section{AUTHORS:}

Anggy Denok Sukmawati: She is a language researcher at the Center for Community and Cultural Research, the Indonesian Institute of Sciences. She is an alumnus of Indonesian Literature at the undergraduate level and majoring in Linguistics at the postgraduate level at the Faculty of Cultural Sciences, Gadjah Mada University. Her latest publication is a review of the book Language and Migration in a Multilingual Metropolitan Berlin Lives, which was published in the Journal of Society and Culture.

Annisa Meutia Ratri: She is a researcher at the Center for Community and Cultural Research, Indonesian Institute of Sciences (LIPI). She has written about the dynamics of Governance structure, Institutional Environment and Informal Structure in Cooperatives with Soft System Methodology and Women's Survival Strategies and Empowerment: The Case study from Indonesian Fisher Women's Collective Action.

Aulia Hadi: She is a researcher at the Indonesian Institute of Sciences' Center for Society and Culture Research (P2MB-LIPI). Her most recent publications include an article entitled 'Bridging Indonesia's digital divide: Rural-urban linkages?' in the Journal of Social and Political Sciences and a chapter entitled 'Jakarta, on the brink of being divided city? Ethnicity, media and social transformation '(co-author) in the book The Routledge Handbook of the Governance of Migration and Diversity in Cities (2019).

Dicky Rachmawan: He is a junior researcher at the Center for Community and Cultural Research (PMB-LIPI) since 2018. He has published an article about "The Pattern of Infrastructure Development Conflict Escalation: A Case Study of Jatigede Reservoir Development" in the period before construction published in the Sociology Journal Socio (2016).

Fachri Aidulsyah: He is the first expert researcher at the Center for Territorial Studies of the Indonesian Institute of Sciences (P2W LIPI). In 2015 he obtained a Bachelor's degree from the Department of Sociology, Gadjah Mada University. The author has been actively involved in conducting research in the field of sociology of religion and ethnonationalism in several regions in Indonesia, Malaysia and the Netherlands since 2014. His latest publication is entitled "Sultanates and the Making of Nationhood in Indonesia and Malaysia" which has been published in the Asian Journal of Social Science.

Fanny Henry Tondo: He is a researcher at PMB-LIPI. He has worked as a consultant for CARE International-Indonesia and an opinion writer for the Sinar Harapan Daily. He has been a speaker at several international scientific meetings including Tokyo-Japan (2015), Seoul-South Korea (2016), Colombo-Sri Lanka (2016), \& California-America (2018). In addition, the author has also taught as an Extraordinary Lecturer at UKI-Jakarta \& UNISMA-Bekasi.

Hidayatullah Rabbani: He is a researcher at PMB-LIPI. Currently, he is completing the postgraduate program in history at Gadjah Mada University, Yogyakarta.

Ibn Nazir: He is a researcher at PMB-LIPI who focuses on social movements and the use of the Internet. He obtained a Masters degree from the Department of Social and Cultural Anthropology at the University of Amsterdam. His latest publication is "The false promise of 'millennials' and the digital economy," which was published in Indonesia at melbourne.unimelb.edu.au in 2020.

Jalu Lintang Yogiswara Anuraga: He is one of the researchers at the Center for Community and Cultural Research-LIPI who was born in Yogyakarta on July 27, 1994. This Yogyakarta-born man is a graduate of UGM Cultural Anthropology in 2017. He joined PMB LIPI in 2018 as a researcher specializing in ethnicity, identity, space travel, and other cultural studies.

Muhammad Nur Prabowo Setyabudi: He is a researcher at the LIPI Society and Culture Research Center (PMB) which focuses on the fields of religion and philosophy. Previously he was educated at the Philosophy Faculty of Gadjah Mada University and was a student at the Al-Muhsin Krapyak Islamic Boarding School, Yogyakarta, the Darussalam Gontor Pesantren Ponorogo, the Nawesea Islamic Boarding School, and the Baitul Hikmah Krapyak Islamic Boarding School, Yogyakarta. His most recent publication is " Filsafat Ilmu dan Logika " which was published in 2020.

Puji Hastuti: She is the first researcher at the LIPI Population Research Center. Her last education was a Bachelor of Social Anthropology, University of Indonesia in 2014. She contributed to the PN Papua health team in 2019 by writing a book entitled Peningkatan Pemanfaatan 
Pelayanan Kesehatan Ibu dan Anak bagi Orang Asli Papua (OAP) in West Papua Province which was published in 2020. by the Torch Foundation.

Russian Fathy: He is the first senior expert researcher at PMB-LIPI in the field of urban sociology since 2018 who was born in Jakarta on July 12, 1994. He is a graduate of S1 education at the Sociology Study Program, Faculty of Social and Political Sciences, UIN Jakarta in 2017. His latest publication is "Fostering Development through Village Owned Enterprise (VEs) in Rural Area: A Comparative Study between Indonesia and China "which was published in 2019.

Sentiela Ocktaviana: Since 2011, she has been a researcher at the Center for Community and Cultural Research-LIPI. She has completed the Master of Development Practice Program at the University of Queensland, Australia, in 2018. Her most recent publication is "Perluasan Akses dan Partisipasi Jaminan Sosial Ketenagakerjaan" which was published in 2020 by the Obor Foundation.

Thung Ju Lan: She is a senior researcher at the Indonesian Institute of Sciences (PMB-LIPI) Society and Culture Research Center. In 1998, she obtained his Ph.D from La Trobe University, Melbourne, Australia. Her most recent publication is a Tinjauan Kritis Ketahanan Sosial Masyarakat Miskin Perkotaan dan Perdesaan: Ruang Sosial, Kebijakan, dan Pola Kerentanan Sosial, along with Aulia Hadi, Soewarsono and Wasisto Raharjo Jati, which was published by LIPI Press in 2019. 